Louisiana State University

LSU Digital Commons

Faculty Publications

Department of Biological Sciences

$11-1-2018$

\title{
Understanding context dependency in the response of forest understorey plant communities to nitrogen deposition
}

\author{
Michael P. Perring \\ Universiteit Gent \\ Martin Diekmann \\ University of Bremen \\ Gabriele Midolo \\ Free University of Bozen-Bolzano \\ David Schellenberger Costa \\ Friedrich Schiller Universität Jena \\ Markus Bernhardt-Römermann \\ Friedrich Schiller Universität Jena
}

See next page for additional authors

Follow this and additional works at: https://digitalcommons.Isu.edu/biosci_pubs

\section{Recommended Citation}

Perring, M., Diekmann, M., Midolo, G., Schellenberger Costa, D., Bernhardt-Römermann, M., Otto, J., Gilliam, F., Hedwall, P., Nordin, A., Dirnböck, T., Simkin, S., Máliš, F., Blondeel, H., Brunet, J., Chudomelová, M., Durak, T., De Frenne, P., Hédl, R., Kopecký, M., Landuyt, D., Li, D., Manning, P., Petř́í, P., Reczyńska, K., Schmidt, W., Standovár, T., Świerkosz, K., Vild, O., Waller, D., \& Verheyen, K. (2018). Understanding context dependency in the response of forest understorey plant communities to nitrogen deposition. Environmental Pollution, 242, 1787-1799. https://doi.org/10.1016/j.envpol.2018.07.089

This Article is brought to you for free and open access by the Department of Biological Sciences at LSU Digital Commons. It has been accepted for inclusion in Faculty Publications by an authorized administrator of LSU Digital Commons. For more information, please contact ir@lsu.edu. 


\section{Authors}

Michael P. Perring, Martin Diekmann, Gabriele Midolo, David Schellenberger Costa, Markus BernhardtRömermann, Johanna C.J. Otto, Frank S. Gilliam, Per Ola Hedwall, Annika Nordin, Thomas Dirnböck, Samuel M. Simkin, František Máliš, Haben Blondeel, Jörg Brunet, Markéta Chudomelová, Tomasz Durak, Pieter De Frenne, Radim Hédl, Martin Kopecký, Dries Landuyt, Daijiang Li, Peter Manning, Petr Petř́ik, Kamila Reczyńska, Wolfgang Schmidt, Tibor Standovár, Krzysztof Świerkosz, Ondřej Vild, Donald M. Waller, and Kris Verheyen 


\title{
Understanding context dependency in the response of forest understorey plant communities to nitrogen deposition
}

\author{
Michael P. Perring a, b, *, Martin Diekmann ${ }^{c}$, Gabriele Midolo ${ }^{\mathrm{d}}$, \\ David Schellenberger Costa ${ }^{e}$, Markus Bernhardt-Römermann ${ }^{e}$, Johanna C.J. Otto ${ }^{e}$, \\ Frank S. Gilliam ${ }^{\mathrm{f}}$, Per-Ola Hedwall ${ }^{\mathrm{g}}$, Annika Nordin ${ }^{\mathrm{h}}$, Thomas Dirnböck ${ }^{\mathrm{i}}$, \\ Samuel M. Simkin ${ }^{\mathrm{j}}$, František Máliš ${ }^{\mathrm{k}, \mathrm{l}}$, Haben Blondeel ${ }^{\mathrm{a}}$, Jörg Brunet ${ }^{\mathrm{g}}$, \\ Markéta Chudomelová ${ }^{\mathrm{m}}$, Tomasz Durak ${ }^{\mathrm{n}}$, Pieter De Frenne ${ }^{\mathrm{a}}$, Radim Hédl ${ }^{\mathrm{m}, \mathrm{o}}$, \\ Martin Kopecký ${ }^{\mathrm{p}, \mathrm{q}}$, Dries Landuyt ${ }^{\mathrm{a}}$, Daijiang Li ${ }^{\mathrm{r}}$, Peter Manning ${ }^{\mathrm{s}}$, Petr Petř́ik ${ }^{\mathrm{p}}$, \\ Kamila Reczyńska ${ }^{t}$, Wolfgang Schmidt " , Tibor Standovár v, Krzysztof Świerkosz w, \\ Ondřej Vild ${ }^{\mathrm{m}}$, Donald M. Waller ${ }^{\mathrm{x}}$, Kris Verheyen ${ }^{\mathrm{a}}$
}

\footnotetext{
${ }^{a}$ Forest \& Nature Lab, Department of Environment, Faculty of Bioscience Engineering, Ghent University, Geraardsbergsesteenweg 267, 9090, MelleGontrode, Belgium

${ }^{\mathrm{b}}$ Ecosystem Restoration and Intervention Ecology Research Group, School of Biological Sciences, The University of Western Australia, 35, Stirling Highway, Crawley, WA, 6009, Australia

${ }^{c}$ Vegetation Ecology and Conservation Biology, Institute of Ecology, FB 2, University of Bremen, Leobener Str. 5, DE-28359, Bremen, Germany

${ }^{\mathrm{d}}$ Faculty of Science and Technology, Free University of Bozen/Bolzano, Piazza Università 5, 39100, Bozen/Bolzano, Italy

e Institute of Ecology and Evolution, Friedrich-Schiller-University Jena, Dornburger Str. 159, DE-07743, Jena, Germany

${ }^{\mathrm{f}}$ Department of Biology, University of West Florida, Pensacola, FL, 32514, USA

${ }^{g}$ Swedish University of Agricultural Sciences, Southern Swedish Forest Research Centre, 230 53, Alnarp, Sweden

${ }^{\mathrm{h}}$ Department of Forest Genetics and Plant Physiology, Swedish University of Agricultural Sciences, Umeå Plant Science Centre, 901 83, Umeå, Sweden

${ }^{\text {i }}$ Spittelauer Lände 5, 1090, Vienna, Austria

${ }^{j}$ National Ecological Observatory Network, 1685 38th St., Suite 100, Boulder, CO, 80301, USA

${ }^{\mathrm{k}}$ Technical University in Zvolen, Faculty of Forestry, T. G. Masaryka 24, 960 53, Zvolen, Slovakia

${ }^{1}$ National Forest Centre, T. G. Masaryka 22, 960 92, Zvolen, Slovakia

${ }^{m}$ Department of Vegetation Ecology, Institute of Botany, The Czech Academy of Sciences, Lidická 25/27, CZ-60200, Brno, Czech Republic

${ }^{\mathrm{n}}$ Department of Ecology, University of Rzeszów, ul. Rejtana 16C, PL-35- 959, Rzeszów, Poland

${ }^{\circ}$ Department of Botany, Faculty of Science, Palacký University in Olomouc, Slechtitelü 27, CZ-78371, Olomouc, Czech Republic

${ }^{\mathrm{p}}$ Department of GIS and Remote Sensing, Institute of Botany, The Czech Academy of Sciences, Zámek 1, CZ-252 43, Prühonice, Czech Republic

${ }^{q}$ Faculty of Forestry and Wood Sciences, Czech University of Life Sciences Prague, Kamýcká 129, CZ-165 00, Prague 6, Suchdol, Czech Republic

'Department of Wildlife Ecology and Conservation, University of Florida, Gainesville, FL, 32611, USA

${ }^{s}$ Senckenberg Biodiversity and Climate Research Centre (SBiK-F), Frankfurt, Germany

${ }^{\mathrm{t}}$ Department of Botany, Faculty of Biological Sciences, University of Wrocław, Kanonia 6/8, PL-50-328, Wrocław, Poland

${ }^{u}$ Department of Silviculture and Forest Ecology of the Temperate Zones, University of Göttingen, Büsgenweg 1, D-37077, Göttingen, Germany

${ }^{v}$ Department of Plant Systematics, Ecology and Theoretical Biology, Eötvös Loránd University, Pázmány P. sétány 1/c, H-1117, Budapest, Hungary

${ }^{\mathrm{w}}$ Museum of Natural History, University of Wrocław, Sienkiewicza 21, PL-50-335, Wroclaw, Poland

${ }^{x}$ Department of Botany, University of Wisconsin - Madison, Madison, WI, 53706, USA
}

\section{A R T I C L E I N F O}

Article history:

Received 15 April 2018

Received in revised form

3 July 2018

Accepted 20 July 2018

Available online 23 July 2018

\begin{abstract}
A B S T R A C T
Understorey communities can dominate forest plant diversity and strongly affect forest ecosystem structure and function. Understoreys often respond sensitively but inconsistently to drivers of ecological change, including nitrogen $(\mathrm{N})$ deposition. Nitrogen deposition effects, reflected in the concept of critical loads, vary greatly not only among species and guilds, but also among forest types. Here, we characterize such context dependency as driven by differences in the amounts and forms of deposited $\mathrm{N}$, cumulative deposition, the filtering of $\mathrm{N}$ by overstoreys, and available plant species pools. Nitrogen effects on understorey trajectories can also vary due to differences in surrounding landscape conditions; ambient browsing pressure; soils and geology; other environmental factors controlling plant growth; and,
\end{abstract}

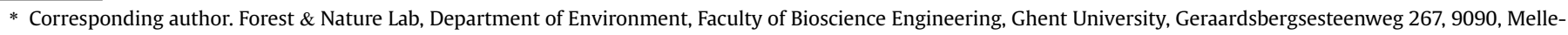
Gontrode, Belgium.

E-mail addresses: michael.perring@uwa.edu.au, michael.perring@ugent.be (M.P. Perring).
} 
Keywords:

Biodiversity

Critical load

forestREplot

Herb layer

$\mathrm{N}$ deposition historical and current disturbance/management regimes. The number of these factors and their potentially complex interactions complicate our efforts to make simple predictions about how $\mathrm{N}$ deposition affects forest understoreys. We review the literature to examine evidence for context dependency in $\mathrm{N}$ deposition effects on forest understoreys. We also use data from 1814 European temperate forest plots to test the ability of multi-level models to characterize context-dependent understorey responses across sites that differ in levels of $\mathrm{N}$ deposition, community composition, local conditions and management history. This analysis demonstrated that historical management, and plot location on light and $\mathrm{pH}-$ fertility gradients, significantly affect how understorey communities respond to $\mathrm{N}$ deposition. We conclude that species' and communities' responses to $\mathrm{N}$ deposition, and thus the determination of critical loads, vary greatly depending on environmental contexts. This complicates our efforts to predict how $\mathrm{N}$ deposition will affect forest understoreys and thus how best to conserve and restore understorey biodiversity. To reduce uncertainty and incorporate context dependency in critical load setting, we should assemble data on underlying environmental conditions, conduct globally distributed field experiments, and analyse a wider range of habitat types.

(C) 2018 Elsevier Ltd. All rights reserved.

\section{Introduction}

In many forests, particularly in temperate and boreal regions, the vast majority of plant biodiversity is in the understorey (Gilliam, 2007). However, much recent ecological research has tended to focus on the forest overstorey potentially at the expense of this critical component of forest ecosystems (Thrippleton et al., 2016). While this research bias, with some notable exceptions (e.g. Verheyen et al., 2012), is true of investigations into nitrogen (N) effects, understorey biodiversity is not immune to the effects of additional N. Such N can come from N-fixing species, rock weathering (Houlton et al., 2018), mineralization or, as focussed on here, atmospheric deposition. Deposited $\mathrm{N}$ tends to promote plant growth and alter nutrient cycles by changing loss pathways and stimulating weathering and mineralization processes (Perring et al., 2008), and thus change plant community composition and soil conditions (Bobbink et al., 1998; Diekmann and FalkengrenGrerup, 1998; Gilliam, 2006). These alterations have important consequences for forest ecosystem functioning, as the composition of the understorey can affect overstorey recruitment, influence pollination dynamics, grazing and browsing dynamics, and nutrient cycling (Nilsson and Wardle, 2005; Gilliam, 2007; George and Bazzaz, 2014; Thom and Seidl, 2016; Strengbom et al., 2018). To aid prediction of future forest functioning and composition, it is thus crucial to understand how and why $\mathrm{N}$ deposition affects understorey plant community composition (Suding et al., 2005; Duprè et al., 2010).

Understorey responses to $\mathrm{N}$ deposition are often hard to generalise as differences in local environmental conditions lead to divergent responses (Nordin et al., 2009; Bobbink et al., 2010; Simkin et al., 2016). Here, we aim to further our understanding of context dependency in $\mathrm{N}$ deposition effects on forest understorey plant community changes. First, we provide a conceptual scheme that outlines potential sources of context dependency in understorey response to $\mathrm{N}$ deposition across and within biomes. We review the evidence for context dependency in $\mathrm{N}$ deposition effects on forest understoreys in temperate deciduous, boreal coniferous, and (sub-) tropical forested biomes, reflecting the geographical bias in published information. We highlight diverging patterns and attendant processes in understorey response to $\mathrm{N}$ within and across these biomes. We then focus on European temperate deciduous forests and capitalise on a large dataset ( $>1800$ resurveyed plots) spread across a gradient in $\mathrm{N}$ deposition to further investigate context dependent responses of the understorey to additional $\mathrm{N}$.

Our review and data analysis reveal the presence of context dependency in understorey community responses to $\mathrm{N}$ deposition, and we discuss the important implications this has for defining critical loads i.e. the level of $\mathrm{N}$ deposition at which deleterious consequences to ecosystem function and composition are apparent (Nilsson and Grennfelt, 1988; Nordin et al., 2005; De Vries et al., 2015; Payne et al., 2017). We also discuss implications for the current and future management, conservation and restoration of understorey communities (e.g. Strengbom et al., 2001). Finally, we outline ways to improve our understanding of context dependency in understorey community change to $\mathrm{N}$ deposition, and, by extension, other environmental stressors.

\section{A conceptual framework for context dependency in understorey community response to $\mathrm{N}$ deposition}

We contend that context dependency in forest understorey response to $\mathrm{N}$ deposition can arise from different sources (Fig. 1). First, and only taking the present into account, $\mathrm{N}$ deposition occurs in different forms and rates across biomes, and thus varied understorey responses in different sites could simply be due to variation in depositional properties. Second, variable overstorey composition within and across biomes will differentially filter atmospheric N deposition compounds (Nordén, 1991; Bergkvist and Folkeson, 1995; Leuschner and Ellenberg, 2017), potentially affecting the forms of $\mathrm{N}$ that reach the understorey, likely favouring species with a preferential ability to take up that form (FalkengrenGrerup, 1995; Näsholm et al., 1998; Falkengren-Grerup et al., 2000; Leuschner and Ellenberg, 2017). Subsequent microbial transformations in the soil, and the ability of some plant species to fix additional $\mathrm{N}$ and support soil biota to further mineralize $\mathrm{N}$, may lead to further differences in the compounds available (Lovett et al., 2004). Third, different biomes and regions have different species pools, biodiversity and functional composition. Thus, variable community responses would be expected across biomes and within regions depending on communities' response trait distribution, with subsequent effects on ecosystem functioning (i.e. the response-effect framework (Suding et al., 2008)). Fourth, interrelated variation in landscape context e.g. distance to forest edge, microclimate, altitude, and moisture conditions that communities find themselves in, together with top-down controls such as fire, grazing, browsing and trophic interactions, including from mycorrhizae, could also influence community change in response to $\mathrm{N}$ (Strengbom et al., 2002; Nilsson et al., 2007; Göransson et al., 2008; Nordin et al., 2009).

Variables that represent the resources and conditions individuals, populations and communities respond to, also influence understorey community development. Our review and analysis 


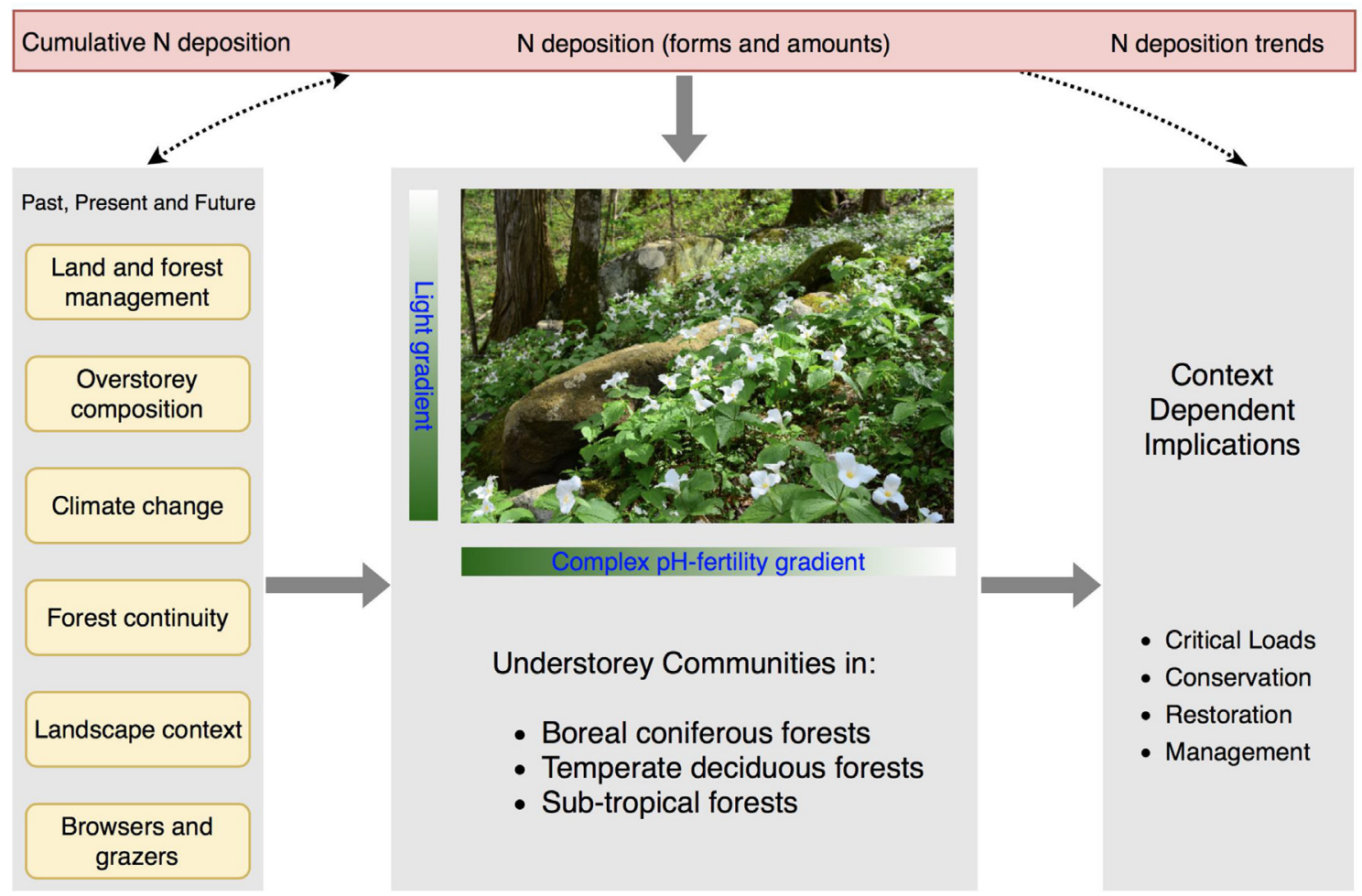

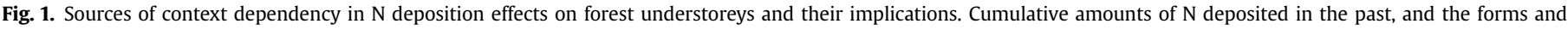

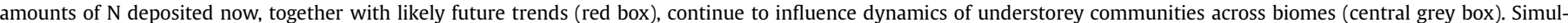

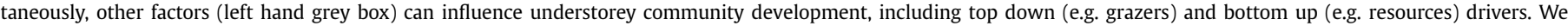

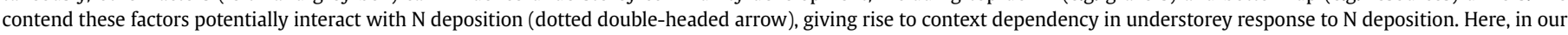

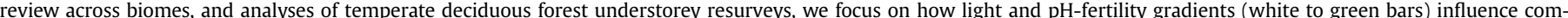

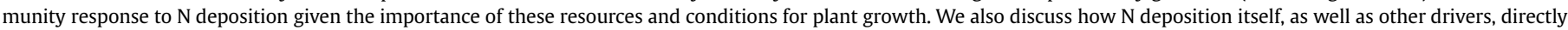

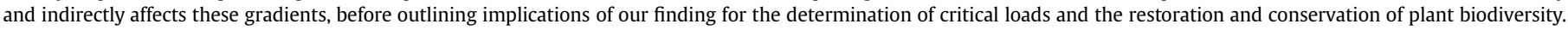
(For interpretation of the references to colour in this figure legend, the reader is referred to the Web version of this article.)

focus on bottom-up gradients in light (due to overstorey composition and forest management) and $\mathrm{pH}$-fertility (due to underlying bedrock, forest management, past acid deposition and overstorey composition). We concentrate on light and $\mathrm{pH}$-fertility because they correspond to important resources and conditions that influence fundamental plant community processes (Vellend, 2010). We expect interactions between the position of a site on these gradients and $\mathrm{N}$ deposition. For instance, soil $\mathrm{pH}$ can precondition subsequent community responses to the effects of increased $\mathrm{N}$ and reduced sulphur (S) deposition (Stevens et al., 2011; Smart et al., 2014). Further, individual species, and plant communities, may respond to additional $\mathrm{N}$ in high light environments but not when under other resource limitations, including in low light environments (Strengbom et al., 2004; De Frenne et al., 2015). Even this expectation may be context dependent, as in other systems, additional $\mathrm{N}$ can increase availability of other nutrients (Treseder and Vitousek, 2001) or improve water use efficiency (Leuschner and Ellenberg, 2017), and thus support increased productivity.

As well as a given understorey's position on these gradients affecting the response to a given amount of $\mathrm{N}$, deposited $\mathrm{N}$ can change a site's position on the gradient. $\mathrm{N}$ deposition can enhance canopy closure, reducing light availability due to increasing tree growth, except where large amounts of $\mathrm{N}$ have led to $\mathrm{N}$ saturation, acidification, and tree mortality and forest decline (Boxman et al., 1998). Concerning pH-fertility, $\mathrm{N}$ deposition can have a complex, compound effect both eutrophying (i.e. fertilizing) but also acidifying a given site (Diekmann and Dupré, 1997), thus perturbing a pre-Industrial Revolution relationship that plants had adapted to between nutrient availability and pH (Falkengren-Grerup, 1990). The acidifying influence could be buffered (alkaline sites) or lead to aluminium $\left(\mathrm{Al}^{3+}\right)$ toxicity in already acidic sites (Brunet, 1994; Lee, 1998; Stevens et al., 2011; Leuschner and Ellenberg, 2017).

The past is another source that we expect to lead to context dependency in response to $\mathrm{N}$ deposition (Perring et al., 2016). History can be multifaceted, but four aspects may be particularly crucial in determining the response of understorey communities to $\mathrm{N}$ deposition: the cumulative amount of $\mathrm{N}$ that has already been deposited in a system (Bernhardt-Römermann et al., 2015); the trend of $\mathrm{N}$ deposition over time; the fragmentation history of the landscape surrounding a given forest plot (Ramalho and Hobbs, 2012); and, management histories within the plot e.g. differences in land use, or differences in land management within a given land use (Perring et al., 2018). In our temperate deciduous forest analysis, we are able to take account of historical forest management given the data available.

\section{A review of published context dependent responses to $\mathbf{N}$ deposition in understorey communities}

We performed a literature review (Appendix A) with the aim to cover understorey community responses to $\mathrm{N}$ deposition across forests globally. We considered various methods that can be used to investigate forest understorey responses to $\mathrm{N}$ deposition (Table A1). We subsequently investigated retained papers in temperate deciduous and mixed forests, boreal coniferous forests, and (sub) tropical forests, to examine the published evidence for understorey 
response to $\mathrm{N}$ deposition and whether responses were context dependent. There were too few papers in other biomes to investigate context dependency in forest understorey response to $\mathrm{N}$ deposition. This geographical bias reiterates the requirement to broaden investigations into $\mathrm{N}$ deposition effects to other study systems, especially in those, such as Mediterranean-type ecosystems, where $\mathrm{N}$ deposition will likely increase in the coming years (Phoenix et al., 2006; Ochoa-Hueso et al., 2017).

\subsection{Temperate deciduous and mixed forests}

Studies from the temperate zone were mostly localized in Europe and North America in mixed deciduous forests, which were at the forefront of industrialization and high-yield agriculture through massive use of mineral fertilizer. Therefore, eutrophication and acidification through $\mathrm{N}$ and sulphur (S) deposition have generally acted upon (northern hemisphere) temperate ecosystems at higher loads and for a longer time period than in the boreal zone or the (sub)tropics. There are now trends for decreasing amounts of $\mathrm{N}$ deposition (Verstraeten et al., 2012). In the tree layer, opencanopy species (e.g. Quercus petraea and Q. robur) have often been replaced by closed-canopy species (e.g. Fagus sylvatica, F. grandiflora, Acer pensylvanicum, A. rubrum) (Norland and Hix, 1996; Becker et al., 2017). The same happened in the shrub layer, where light-demanding species such as Cornus sanguinea have decreased (Thimonier et al., 1992). Overstorey impacts are context dependent. Under high $\mathrm{pH}$ levels, and in floodplain forests, Ulmus spp. can increase cover and biomass at the expense of Alnus spp. and Fraxinus excelsior, while under acidic conditions, Betula pendula may be replaced by Prunus serotina (Naaf and Kolk, 2016). Overstorey dynamics can also be due to changed forest management practices and the actions of browsers and grazers (Corney et al., 2008; Müllerová et al., 2015), which confounds simple assignment of the abovementioned changes being due to $\mathrm{N}$ deposition (although note Hättenschwiler and Körner, 1997; De Vries et al., 2014).

The understorey has exhibited directional change in conjunction with this tendency for a thickening overstorey (referred to as mesophication in North America). These changes include a homogenization of biota (Gilliam, 2006), and a loss of specialist species that have been replaced by acidophilous and nitrophilous species. In the herb layer, spore plants adapted to low-light environments, such as Dennstaedtia punctilobula, but also seed plants such as Hedera helix and Oxalis montana have become more abundant, at the expense of species adapted to less shady and less nutrient-rich conditions, such as Alliaria petiolata and Galium aparine (Gilliam, 2006).

Substantial context dependency in temperate forest understorey response to $\mathrm{N}$ deposition (Table 1 ) is masked by these general statements. The degree of canopy openness determines if light will be a limiting factor after soil $\mathrm{N}$ availability increases through deposition. In the herb layer, species such as Mercurialis perennis and Oxalis acetosella profit from high nutrient levels under closed canopies, while open forest species such as Melampyrum pratense and Tanacetum corymbosum disappear under high nutrient levels (Heinrichs and Schmidt, 2017). Under open-forest conditions, lightdemanding species such as Anemone nemorosa increase strongly in growth at the expense of species such as Primula elatior and Viola reichenbachiana (Thimonier et al., 1992; Bernhardt-Römermann et al., 2010; Jantsch et al., 2013).

Substantial context dependency in understorey response to $\mathrm{N}$ deposition can also arise due to natural variability in different bedrocks (e.g. sandstone vs limestone) and subsequent differences in $\mathrm{pH}$ and nutrient levels. In the herb layer, the fern Dryopteris dilatata, the grass Deschampsia flexuosa, the moss Hypnum cupressiforme, and the liverwort Lophocolea heterophylla are examples of species profiting from higher nutrient levels on acidic soils (Rodenkirchen, 1992). While $\mathrm{N}$ is often assumed to be the limiting nutrient in temperate soils, phosphorus $(\mathrm{P})$ limitation also occurs in several regions (Hofmeister et al., 2002; Tessier and Raynal, 2003). In such plots, increases in N deposition will likely have weak or no effect, unless it stimulates production of enzymes to increase $\mathrm{P}$ availability and subsequent stimulation of plant growth. Besides natural variability, forest management practices have had a strong impact, including forest conversion in Europe to Norway spruce (Picea abies) plantations. We exclude spruce plantations from our review because they are coniferous, heavily managed, and differ strongly from the deciduous types. However, we do consider the legacy effects of widespread historical management practices in European temperate deciduous forests (McGrath et al., 2015). Grazing and browsing can also lead to shifts in species composition, and with increased $\mathrm{N}$ deposition, they may favour unpalatable species, independent of the growth rate of others (Bernhardt-Römermann et al., 2015). Species preferred by many browsers such as Hedera helix and Vaccinium myrtillus can be significantly reduced (Reczyńska and Świerkosz, 2017). Grasses often profit from high browsing intensity, as they are often avoided by browsers/grazers in the forest. Examples include Millium effusum and Poa nemoralis (Corney et al., 2008; Reczyńska and Świerkosz, 2017).

\subsection{Boreal coniferous forests}

Boreal forests, and high montane coniferous forests of the temperate zone, differ from deciduous and mixed forests in temperate regions in that they are generally dominated by few coniferous tree species, with nutrient-poor and acid soils also being more common. In northern Europe where most $\mathrm{N}$ deposition studies were carried out, only two tree species (Pinus sylvestris and Picea abies) make up most of the standing timber volume. The understorey is comparatively poor in vascular plant species and often characterized by dwarf shrubs (Vaccinium spp.). The ground layer is diverse, with many bryophytes and, on sites with little soil moisture, lichens. Boreal coniferous forests are exposed to relatively low levels of $\mathrm{N}$ deposition, in Europe decreasing from slightly above $10 \mathrm{~kg} \mathrm{~N} \mathrm{ha}^{-1} \mathrm{y}^{-1}$ in the south to very low (almost ambient) levels in the north (Akselsson et al., 2010). Despite low human population densities in the boreal parts of North America and Eurasia, large parts of the European, and to some extent Canadian, boreal forests are managed for timber production with artificial regeneration methods, improved seedling material and biologically short rotations, which results in uniform, dense canopies. This management is a confounding factor for $\mathrm{N}$ deposition effects especially through its impact on light availability in the understorey (Hedwall and Brunet, 2016; Hedwall et al., 2017b), similar to temperate forests.

Evidence for the effects of $\mathrm{N}$ deposition in boreal forests (see also Binkley and Högberg, 2016) comes from temporal, spatial and experimental studies, the latter often using unrealistically high $\mathrm{N}$ doses, given the low $\mathrm{N}$ deposition levels. In general, $\mathrm{N}$ deposition effects on the understorey are relatively weak possibly due to colimitation by $\mathrm{P}$ (Hedwall et al., 2017a) and the low $\mathrm{N}$ deposition amounts. A confounding factor difficult to quantify is the effect of large browsers (moose and roe deer) that have shown considerable fluctuations in their populations densities over the last century (e.g. Hedwall et al., 2018).

The responses of understorey species to $\mathrm{N}$ deposition depend on canopy cover (Table 2). For instance, Vaccinium spp. species often dominate the field-layer vegetation and their $\mathrm{N}$ responses are mediated by tree canopy closure. In an open forest, the abundance 
Table 1

Summary of the published literature on context-dependent responses of understorey species' groups to N deposition in temperate deciduous and mixed forests.

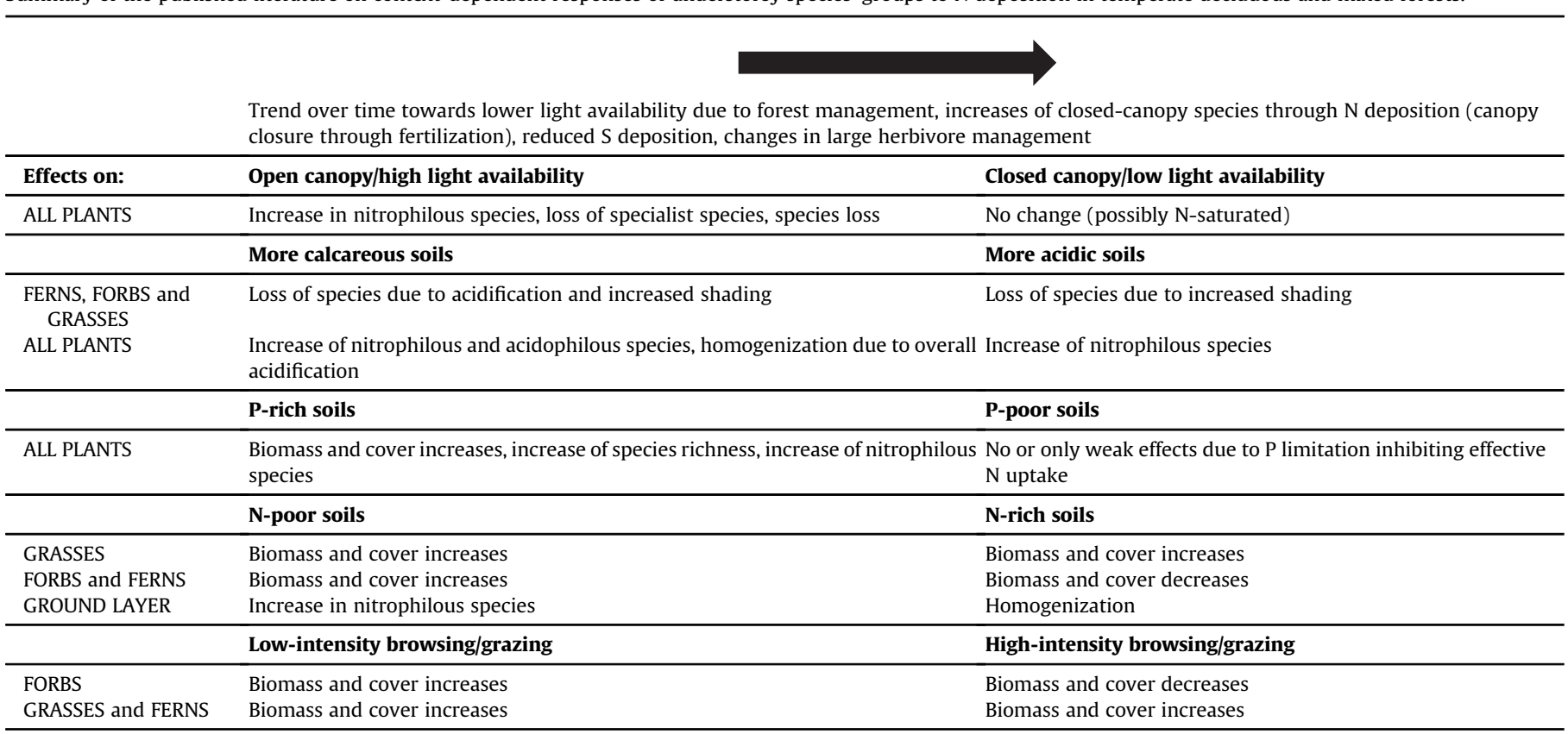

of $V$. myrtillus may increase as $\mathrm{N}$ increases, while in a low light environment the species may be indifferent to $\mathrm{N}$ or even decrease (Nordin et al., 2009; Strengbom et al., 2018). A negative effect of $\mathrm{N}$ on $V$. myrtillus can be induced by the positive effect of increasing $\mathrm{N}$ on the incidence of the fungal leaf pathogen Valdensia heterodoxa and on herbivore larvae (Strengbom and Nordin, 2012). Similarly, the common graminoid Deschampsia flexuosa shows a strong increase with $\mathrm{N}$ deposition, but only under sufficient light (Strengbom et al., 2004). Forbs often respond positively to $\mathrm{N}$ deposition (as suggested from experiments e.g. Grainger and Turkington, 2013) even under low light and the same is true for some ferns (Athyrium filix-femina, Dryopteris spp.) being tolerant of both shade and low $\mathrm{pH}$. In forests with a more open canopy the positive responses of these species are less distinct, possibly due to the larger competitive strength of grasses and dwarf shrubs. $\mathrm{N}$ deposition effects on forbs and ferns may be confounded by climate change in that many of the species respond positively to increasing temperatures and precipitation.

Table 2

Summary of the published literature on context-dependent responses of understorey species' groups to N deposition in boreal forests, with a focus on light gradients.

\begin{tabular}{|c|c|c|c|}
\hline \multirow[b]{2}{*}{ Effects on: } & \multicolumn{3}{|c|}{$\begin{array}{l}\text { Trend over time towards lower light availability due to forest management and } \mathrm{N} \text { deposition (canopy closure through fertilization), longer growing season } \\
\text { and higher precipitation (especially in drought-limited pine forests) }\end{array}$} \\
\hline & High light availability & Low light availability & Confounding factors: \\
\hline $\begin{array}{l}\text { DWARF } \\
\text { SHRUBS }\end{array}$ & unclear; responses inconsistent & (-) weak negative effects on Vaccinium (myrtillus) & $\begin{array}{l}\text { - fungal leaf pathogens (Valdensia } \\
\text { heterodoxa) under low light and larvae of } \\
\text { herbivores on Vaccinium myrtillus are } \\
\text { favoured by } \mathrm{N} \text { deposition }\end{array}$ \\
\hline FERNS & $\begin{array}{l}\text { (+) Growth weakly favoured by } \mathrm{N} \text { deposition due to } \\
\text { the large tolerance of Dryopteris spp. to low soil pH } \\
\text { (but less competitive at high light levels) }\end{array}$ & $\begin{array}{l}+ \text { Growth favoured by } \mathrm{N} \text { deposition due to the large } \\
\text { tolerance of Dryopteris spp. and Athyrium filix-femina to } \\
\text { low soil pH and low light levels }\end{array}$ & $\begin{array}{l}\text { + warmer temperatures and higher } \\
\text { precipitation (humidity) }\end{array}$ \\
\hline FORBS & $\begin{array}{l}\text { Relatively weak or unclear trends; }(+) \text { positive effects } \\
\text { on ruderals }\end{array}$ & $\begin{array}{l}+ \text { positive trend, probably due to higher competitive } \\
\text { abilities compared to dwarf shrubs and grasses under } \\
\text { low light (increase shown e.g. for Epilobium } \\
\text { angustifolium and Rubus idaeus), possibly also Oxalis } \\
\text { and Trientalis }\end{array}$ & $\begin{array}{l}\text { + warmer temperatures and higher } \\
\text { precipitation }\end{array}$ \\
\hline GRASSES & + Strong increase in Deschampsia flexuosa & $\begin{array}{l}\text { No clear effect; Deschampsia may decrease when light } \\
\text { levels become too low even with } \mathrm{N} \text { deposition }\end{array}$ & $\begin{array}{l}\text { - Deschampsia suffering from acidification } \\
\text { (+indirectly favoured when Vaccinium is } \\
\text { attacked by Valdensia) }\end{array}$ \\
\hline BRYOPHYTES & $\begin{array}{l}\text { - mostly decreasing as under low light, but even } \\
\text { stronger negative competitive interactions with field } \\
\text { layer species and trees that in turn are favoured by } \mathrm{N} \\
\text { deposition }\end{array}$ & $\begin{array}{l}\text { No uniform results, but in most studies decrease in } \\
\text { typical conifer companions (Pleurozium, Dicranum } \\
\text { polysetum), increase in others (Brachythecium, } \\
\text { Plagiothecium); both direct (high amino acid } \\
\text { concentration) and indirect (competition) negative } \\
\text { effects }\end{array}$ & $\begin{array}{l}\text { + mosses probably indirectly favoured by } \\
\text { strong acidification and very low light levels }\end{array}$ \\
\hline LICHENS & - clearly decreasing & normally largely absent & \\
\hline
\end{tabular}




\subsection{Sub-tropical and tropical forests}

The lack of published work on understorey dynamics in (sub)tropical forests in response to $\mathrm{N}$ deposition makes this section brief. Nevertheless, there is evidence for context dependence in the response of tropical and subtropical forest understorey communities, as these few studies suggest that different mechanisms operate to those driving responses in temperate and boreal forests. In subtropical forests, excess $\mathrm{N}$ typically decreases plant diversity by directly reducing the performance of understorey communities, that can comprise numerous woody plant species' seedlings from the overstorey (Lu et al., 2010, 2011; Both et al., 2012). This direct effect arises from several factors, but most especially from reduction in fine root biomass from $\mathrm{N}$-mediated increases in acidity of poorly-buffered tropical soil, along with associated increases in aluminium mobility (Lu et al., 2014). In contrast, in temperate forests, any $\mathrm{N}$-mediated loss of species typically results from changes to competitive dynamics and a homogenization of environmental conditions (Gilliam, 2006; Gilliam et al., 2016). Thus, as well as context dependency in responses to $\mathrm{N}$ deposition due to resources and conditions (e.g. soil differences), context dependency can arise between biomes due to the characteristics of the different species pools that make up the understorey layer. We are unable to extend our analysis to the understories of other forested biomes e.g. those of Mediterranean climates, since the limited works published do not allow an assessment of context dependence within or among other biomes.

\section{Illustrating the conceptual framework: context dependent understorey community responses to $\mathrm{N}$ deposition in temperate European deciduous forests}

\subsection{Methods}

The review suggests that context dependent responses to $\mathrm{N}$ deposition can occur across biomes, but the papers presented tended to lack a broad-scale investigation into such a phenomenon. We therefore tested expectations from our conceptual framework by capitalising on a dataset of 1814 plots (forestREplot, www. forestreplot.ugent.be) distributed across the European temperate deciduous forest biome (see Appendix B). Our aims were manifold. First, to illustrate the potential of a multi-plot, multi-region analysis to aid understanding of global change effects on biodiversity (Verheyen et al., 2017). Second, to ask whether there is evidence for context dependency in forest understorey responses to $\mathrm{N}$ deposition in a coherent, continental-scale dataset. Third, to provide some plausible explanations for any observed context dependency. Here, we describe our analyses to ascertain and understand context dependency in $\mathrm{N}$ deposition effects on forest understoreys. Full methodological details, and statistical results, are available in Appendix B.

To estimate community change through time, applying a log response ratio, we used resurveys of cover of understorey vascular plant species, across available forestREplot data in European forests. We characterised fundamental descriptors of plant communities at the time of initial and most recent surveys i.e. trait community weighted means of specific leaf area (SLA), seed mass and plant height using values derived from databases; species richness; and species' cover, based on structural/functional life form (sensu Box, 1996).

We adopted a two stage, multi-level model analysis approach using R (R Core Team, 2017). The first stage asked whether there was any evidence for $\mathrm{N}$ deposition effects on understorey community change accounting for other methodological and ecologically relevant variables at the plot and regional scale in an additive fashion (Table B1). We also accounted for the nested nature and spread of the data i.e. plots within regions, and varying spreads by region, through fitting statistical models that used random intercepts and different weights by region (Zuur et al., 2009; Pinheiro et al., 2016). We considered evidence for an effect of $\mathrm{N}$ in this first stage to be significant $(\mathrm{p}<0.05)$ parameter estimates i.e. a slope estimate greater than $|0|$.

The second stage of our analysis asked whether there was any evidence for context dependency along inferred environmental gradients, of light and of compound pH-fertility, and due to plot management history. We inferred environmental gradients, using community cover weighted mean Ellenberg Indicator Values (EIV) for light, $\mathrm{pH}$ and nutrients at the time of the initial survey, because directly measured environmental data were not available for all plots. These values indicate species associations with particular environmental conditions. As noted by Diekmann (2003), such values provide a relatively robust means of characterising environmental growth conditions, particularly within single vegetation types and when used with appropriate care (Schaffers and Sýkora, 2000; Dzwonko, 2001; Wamelink et al., 2002). Given that we expect vegetation change to be lagged, this is an imperfect solution i.e. the values at the time of the initial survey may not precisely reflect the environmental conditions at the time of the survey. In addition, explaining vegetation change via covariates that are derived from the vegetation, is not ideal, but circularity of argumentation is mainly avoided as the original designation of EIV was not based on the sample plots we analyse. As we emphasize in the Discussion, future work should prioritise characterising the environment directly, as well as recording understorey composition, while care should be taken in interpreting results from observational studies such as this (Smart et al., 2012).

Previous conditions can influence community responses to current $\mathrm{N}$ deposition, especially if such management had altered resources and conditions for plant growth (Perring et al., 2016). Here, we considered historical influences by deriving management histories for plots through expert testimony. Analysed plots were distributed across two widely used management systems in 19th Century Europe: coppice with standards (CWS) and high forest (HF) (McGrath et al., 2015). These systems had very distinct harvesting and disturbance regimes (Matthews, 1989; Rackham, 2003) that led to differences in resources and conditions, and associated plant communities (Decocq et al., 2004; Keith et al., 2009).

Light and $\mathrm{pH}$-fertility initial survey values were not strongly correlated with each other (Spearman's rho of -0.48) despite expectations to the contrary (e.g. Lameire et al., 2000). Neither of the gradients were strongly related to initial management (see Supplementary Information and Perring et al., 2018), and so all three explanatory values could be included in full interaction models. In this second stage of the analysis, we considered evidence for context dependency in $\mathrm{N}$ deposition response to be shown by a significantly lower (via a likelihood ratio test) Akaike Information Criteria (AIC) for an interaction model compared to the simple model retained from the first stage of the analysis. We also used $\mathrm{R}^{2}$ to help ascertain the most likely explanation for community responses (Nakagawa and Schielzeth, 2013).

To aid interpretation and description of community change, we also calculated log response ratios for EIV, and followed the same two-stage model selection procedure outlined above. We examined changes between surveys in cover-weighted EIV for temperature and moisture, as well as EIV response ratios for light, nutrients, and reaction. Changes in indicator values may indicate alterations in resources and conditions, and thus provide some indication of what is driving community change. 


\subsection{Results}

Plant community change between surveys, as measured by functional traits, species richness and structural composition, rarely depended on $\mathrm{N}$ deposition as a main effect, although indicator value changes for $\mathrm{pH}$ and temperature between surveys responded to $\mathrm{N}$ deposition alone (Table $\mathrm{B} 2$ ). The lack of a simple main $\mathrm{N}$ deposition effect on most community change variables between surveys confirms earlier analyses within the forestREplot database (Verheyen et al., 2012; Bernhardt-Römermann et al., 2015). Some understorey community variables, including species richness, mean SLA, seed mass and fern cover, showed no evidence for responses being due to $\mathrm{N}$ deposition, either simply or in a context dependent manner. However, remaining fundamental community properties did show evidence for context dependency, mainly as different linear slopes along the $\mathrm{N}$ deposition gradient, although this was quadratic for forbs. Multi-level interactive models explained substantial portions of variation in response ratios (e.g. between 25 and 73\%; Table B2).

Context dependency was clearly demonstrated for understorey vegetation height change between surveys (Fig. 2; $40 \%$ of variation in response explained). $\mathrm{N}$ deposition strongly interacted with both management in 1800 and the plot position at the time of the initial survey on a complex pH-fertility gradient. For management in 1800, the interaction paralleled that found in Perring et al. (2018) and showed that with additional $\mathrm{N}$, height can decrease in formerly coppiced sites (Fig. 2a) or increase in HF sites (Fig. 2b). These responses also depended on the underlying complex $\mathrm{pH}-$ fertility gradient. The decline in height with $\mathrm{N}$ deposition in former coppice sites was predicted to be less evident in nutrient poor, acidic sites as compared to richer sites, with higher floral indicator values for $\mathrm{pH}$ and fertility (Fig. 2a, compare red and blue lines). This greater loss of height may be due to a closing of the canopy and retention of smaller, more shade-tolerant plants in the understorey. In contrast, the increase in understorey vegetation height with $\mathrm{N}$ deposition in former HF sites was even greater in nutrient-poor, acidic sites while in rich sites, additional $\mathrm{N}$ was predicted to have little effect on community change (Fig. 2b).

Forbs, and particularly graminoids, showed evidence for community change between surveys being due to an interaction between $\mathrm{N}$ deposition and another resource gradient, the light environment. For graminoids, in sites initially characterised by high light species assemblages (blue line in Fig. 3a), low amounts of $\mathrm{N}$ deposition led to increases in graminoid cover between surveys, while large amounts of $\mathrm{N}$ deposition led to decreased graminoid cover. In communities initially characterised by plants with low demand for light (red line in Fig. 3a) the response to $\mathrm{N}$ deposition was in the opposite direction (i.e. decreases in graminoid cover under low levels of $\mathrm{N}$ and increases with high levels of $\mathrm{N}$ ) but the slope was close to zero. Species' characteristics within the graminoid group could account for these differences between assemblages, as narrow and broad-leaved grasses may show different tolerances to shade, and variation in nutrient demand. Forbs showed the opposite response to graminoids, although there was limited cover change under low $\mathrm{N}$ deposition levels, regardless of the indicated light environment. However, under high levels of $\mathrm{N}$ deposition, forb cover increased in communities initially characterised by a high demand for light and decreased in communities characterised by low light demand (Fig. 3b). Overall, these responses likely reflected the dominance of forbs in the dataset as a whole, and that where graminoids were present, they tended to be shade-tolerant species, with plots often including sedges as well as grasses (see Figs. B2 and B3, Supplementary Material). Such shade tolerant species tend to be less capable of rapid biomass accumulation in response to both increased light and $\mathrm{N}$ and will thus contribute less to community change.

Light indicator response ratios showed interactions between management type in 1800 and $\mathrm{N}$ deposition, together with a dependence on initial survey $\mathrm{pH}$-fertility (Fig. B4). Interestingly, the direction of change in light response along the $\mathrm{pH}$-fertility gradient was similar to that observed for understorey vegetation height. This suggests that the change in understorey height observed in 1800 coppice and high forest systems could be related to species' preferences for light. Cover of species that prefer darker conditions increased in high fertility sites as $\mathrm{N}$ deposition rate increased particularly in former CWS sites, and this was accompanied by a decline in vegetation height (cf. Fig. 2a with Fig. B4a). In contrast, the increase in vegetation height in response to $\mathrm{N}$ deposition in low fertility sites in HF of 1800 was reflected in a greater cover of lightdemanding plants, as the light response ratio was positive (cf. Fig. 2b with Fig. B4b).

\section{Implications of context dependency in understorey responses to $\mathrm{N}$ deposition}

The results from our analysis have direct implications for the interpretation of critical loads and for conservation and restoration of communities. The restriction of our analysis to European deciduous temperate forests argues for greater efforts to investigate other biomes.

\subsection{Critical loads}

A critical load is defined as "a quantitative estimate of an exposure to one or more pollutants below which significant harmful effects on specified sensitive elements of the environment do not occur according to present knowledge" (Nilsson and Grennfelt, 1988). Vegetation changes are the typical biological endpoint considered in setting critical loads for eutrophication from reactive $\mathrm{N}$ (De Vries et al., 2015). However, critical loads can vary among species within communities, and within species depending on the environmental context (Henrys et al., 2011; Payne et al., 2013). Regarding context dependency, we can differentiate between critical load approaches, namely empirical and model-based.

Empirically-calculated critical loads approaches (Bobbink and Hettelingh, 2011; Pardo et al., 2011; Simkin et al., 2016) can benefit from readily incorporating a very large number of preexisting observations from field sites that with care can span heterogeneous ecological contexts. However, they are often set regardless of particular conditions and our results suggest that consideration of forest-management history, fine-resolution light availability and underlying fertility could substantially shift many existing critical loads. For example, our results indicate that in forests with frequent biomass removal in the past (e.g. coppiced or other methods) critical loads of $\mathrm{N}$ deposition for understorey vegetation height are considerably lower and therefore more risk averse than for less-altered forests (e.g. high forests). Critical loads could be adjusted further according to the species pool, and fertility context, of the site. Fertile sites predisposed light-demanding species to decline in HF exposed to high rates of $\mathrm{N}$ deposition, with this decline even more pronounced in CWS. In a different context of lower fertility, shade-tolerant species held steady in former CWS or even increased in HF in response to $\mathrm{N}$ deposition. Thus, what might appear to be low critical loads for $\mathrm{N}$ deposition for understoreys in one context are not apparent in another context.

Model-based critical loads complement empirical approaches. When using model-based approaches, acidifying effects of deposition from $\mathrm{S}$ and $\mathrm{N}$ compounds and historic management effects (e.g. litter raking) on soil nutrient depletion and acidity are also 

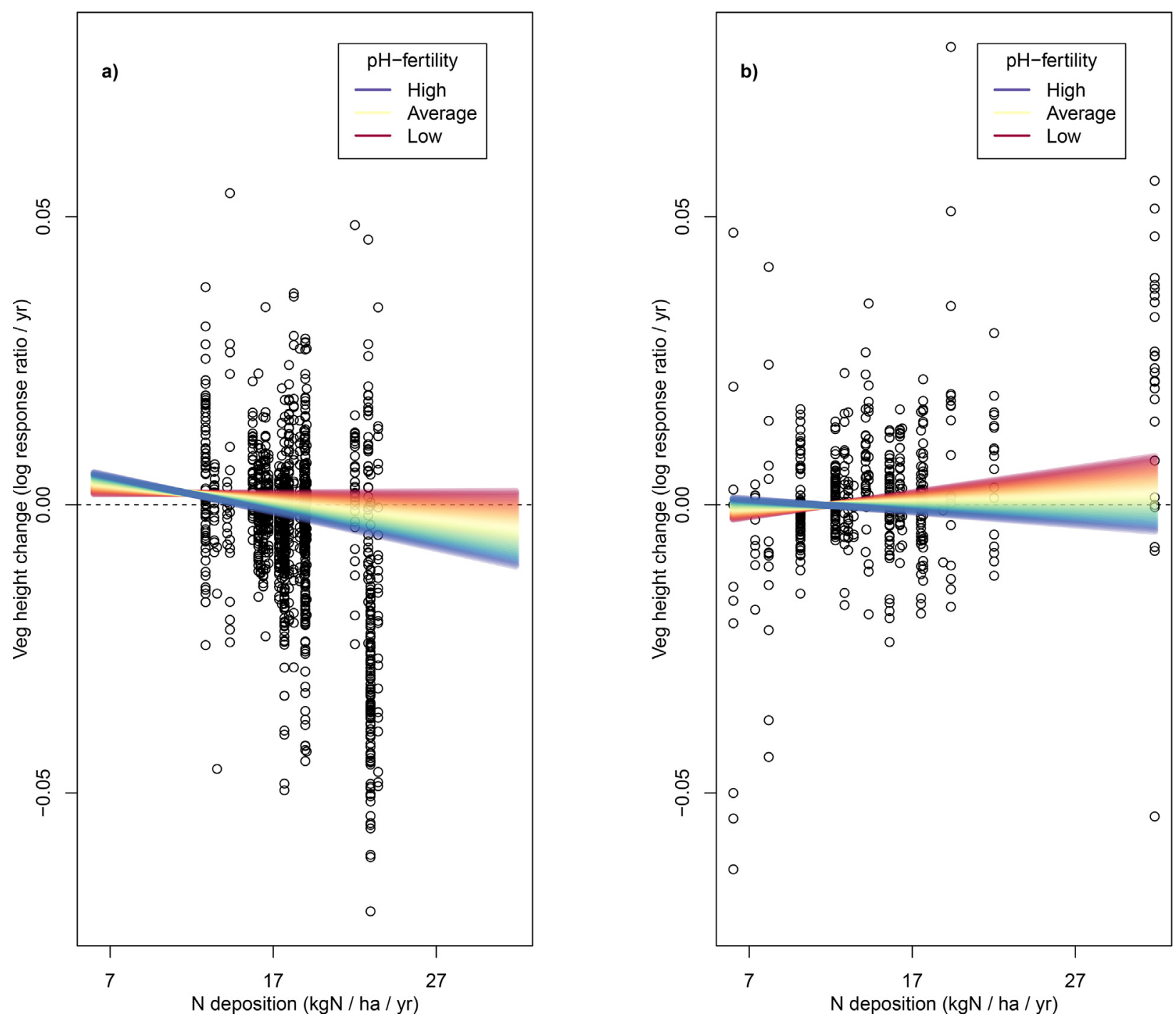

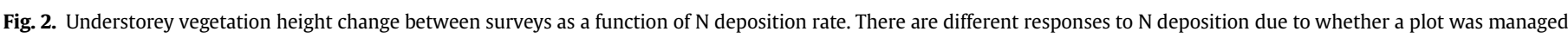

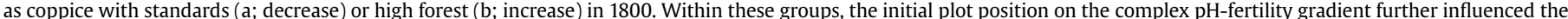

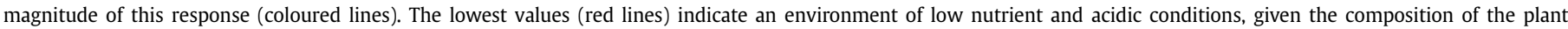

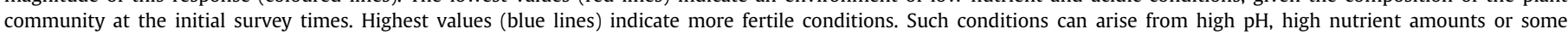

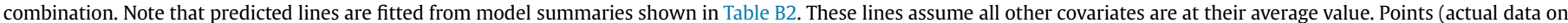

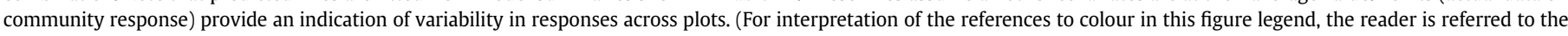
Web version of this article.)

included because parameters such as cation exchange capacity and related cation exchange processes are used to derive the critical load (De Vries et al., 2015). Climate change effects on base cation weathering, seepage flux, and $\mathrm{N}$ retention (uptake, immobilization, etc.) are integrated in the critical load calculation. Context dependency in the response of forest understorey to $\mathrm{N}$ deposition should not be too critical, at least to other major drivers, when using a mass balance approach. Increasingly, the dynamic modelling approaches for air pollution effects on biodiversity, that have been developed in the course of the critical load work (De Vries et al., 2010), are applied to account for confounding effects. Rizzetto et al. (2016) and McDonnell et al. (2014) have all studied potential climate impacts on $\mathrm{N}$ deposition effects, with the latter finding a strong influence from warming driven tree growth changes, resulting in oligotrophication of forest understorey vegetation, offsetting $\mathrm{N}$ deposition effects to different degrees. These and other effects, such as management, though readily incorporated in the model-based critical load approach, are only starting to being addressed in the policy context (Hettelingh et al. 2017).

\subsection{Forest understorey management, conservation and restoration}

Evidence-based restoration and conservation aiming at altering understorey plant biodiversity dynamics in forests should reflect context dependency and consider drivers operating at various scales. Previously, observed change in vegetation in a subset of the plots analysed in this study was assigned to overstorey dynamics between surveys rather than $\mathrm{N}$ deposition (Verheyen et al., 2012). Increased overstorey cover potentially led to increased litter deposition and a build-up of nutrients in the forest floor. The nutrients accumulated in litter, in addition to deposited N, might then rapidly release and have negative biodiversity consequences for understorey vegetation when canopies open up again. This so- 

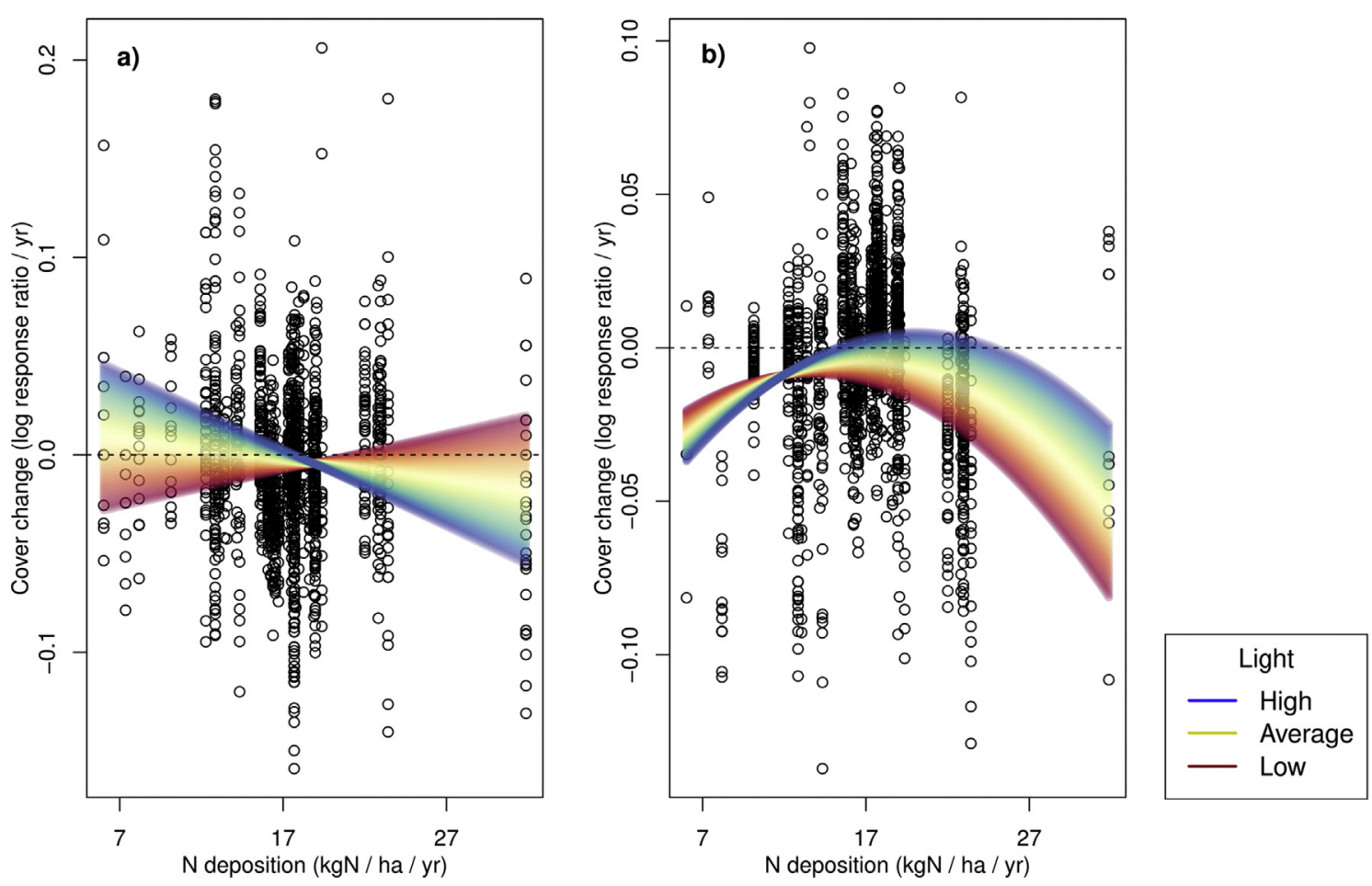

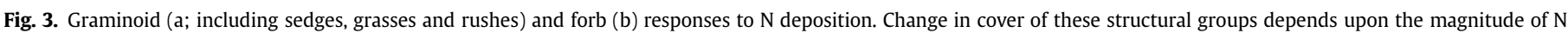

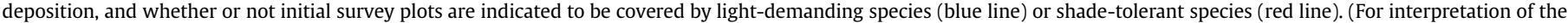
references to colour in this figure legend, the reader is referred to the Web version of this article.)

called "N time bomb" (Verheyen et al., 2012) has to be considered in the restoration of coppice systems, particularly as canopy opening may lead to an increase of nitrophilous species, due to potentially increased microbiological activity increasing $\mathrm{N}$ availability (although note Averill and Waring, 2018), in conjunction with increased light availability through canopy opening.

Here, we have extended this previous analysis to show that $\mathrm{N}$ deposition can interact with such historical management to influence community dynamics, and that these trajectories further depend upon underlying plot fertility and $\mathrm{pH}$. Depending on the goals of restoration and conservation (e.g. return to a pre-existing condition with particular species vs a community resilient to future change), our findings argue for careful consideration of current and previous local conditions when making conservation and restoration recommendations. Specificity of measures may depend on the underlying fertility of sites and the shade casting ability of the overstorey. In addition, managers need to be aware that reaching goals for understorey plant diversity through opening the canopy may compromise the successful recovery of plant communities for reasons other than the $\mathrm{N}$ time bomb. Forest stand structure controls the microclimate and loss of microclimate buffering induces a process described as thermophilization, i.e. an increase in dominance of warm-adapted over cold-tolerant plants (De Frenne et al., 2013). An experiment in a Belgian forest showed the combination of microclimate warming with higher amount of light at the understorey level, or even with $\mathrm{N}$, induce the largest community shifts and thermophilization rates (De Frenne et al., 2015). Warming might also promote the invasion of non-native species (Bellard et al., 2013) or even accelerate the process of biotic homogenization (see also Fig. B4c and d), especially if climate change causes more species range expansions than contractions (Savage and Vellend, 2015). Microclimatic changes associated with a broadscale reintroduction of historic management regimes could also have detrimental effects on other elements of forest biodiversity, such as epiphytic bryophytes, which depend upon high humidity.

Conservation management could consider the landscape level, and perhaps introduce open rides (as typical of many British woodlands) or smaller scale cuttings, which may then promote the light demanding part of a typical CWS flora regardless of $\mathrm{N}$ deposition. These smaller scale interventions would maintain higher humidity and closed canopies in other areas, and avoid the negative consequences of losing microclimate buffering (Senior et al., 2018). These contentions require further experimental testing across contexts to provide the evidence-based recommendations required. Current experiments have shown positive biodiversity effects (Vild et al., 2013; Douda et al., 2017) but their results cannot be generalized across regions because of the high spatial variability in land-use legacies, $\mathrm{N}$ deposition loads and other drivers of temporal change in vegetation (Bernhardt-Römermann et al., 2015; Chudomelová et al., 2017).

\section{Furthering understanding of context dependency in $\mathbf{N}$ deposition effects on forest understoreys}

We used a multi-level resurvey analysis across forest regions to demonstrate context dependency in the response of understorey communities to $\mathrm{N}$ deposition. However, as our conceptual framework (Fig. 1) makes clear, multiple interacting factors drive this change. For resurvey studies, careful choice of sites could improve the ability to disentangle environmental factors by improving orthogonality among potential drivers (Verheyen et al., 2017). Our analysis was constrained by available plots in the forestREplot database. On the one hand, this meant correlation among focal explanatory variables was low, thus allowing the analysis we performed. On the other hand, some variables had short gradient 
lengths (e.g. temperature) or were correlated (see Supplementary Information and Perring et al., 2018). Future investigations could thus target particular sites to extend the coverage of multidimensional environmental space and improve orthogonality (e.g. Gillespie et al., 2017). To understand the relative importance of different environmental factors, and their relationships with each other, a structural equation modelling approach may be beneficial. In addition, meta-analyses across sites can reveal context dependency in critical loads within and among understorey plant species. Combining empirical approaches with simulation modelling to project changes in the light of management actions may further guide understorey conservation and restoration efforts (Landuyt et al., 2018). Globally distributed experiments may be an additional means to understand context dependency in understorey response to environmental stressors (Fraser et al., 2013), including the consequences of declining $\mathrm{N}$ deposition (Stevens, 2016). Relatively low cost interventions across a range of sites, with clear guidelines on implementation and collaboration, would lead to increased understanding (Borer et al., 2014). Such interventions could include actions to ascertain when the reintroduction of coppice management will be beneficial, and when it could be detrimental, for the achievement of stated goals.

Our analysis assumed that differences in $\mathrm{N}$ deposition amounts were the driving force of any interactions with underlying environmental gradients. It could be that observed responses are also due to differences in $\mathrm{N}$ forms among sites, or unmeasured factors such as grazing and browsing animals or management actions between surveys. The attribution of context dependency to underlying gradients, and understanding of mechanisms, would be helped by direct characterisation of underlying environmental resources and conditions, and extending the range of investigated conditions. Future research should prioritize detailing additional environmental variables as well as plant community descriptions. In forests where underlying environmental variables are already being recorded, it would be beneficial to characterise understorey communities. As well as prioritising description of community response, the implications of observed understorey changes for ecosystem functioning and ecosystem service delivery need elucidating.

\section{Concluding remarks}

Our qualitative review of the published literature on, and illustrative analysis of, forest understorey responses to $\mathrm{N}$ deposition show that plant community change is context dependent. We argue that context dependence can arise due to a number of sources, ranging from broad-scale differences in the forms and amount of $\mathrm{N}$ deposited and plant species pools available, to site and landscape context differences, including historical management practices, at the plot scale. Furthermore, context dependence in community responses is common among ecosystems, and suggests that a similar conceptual framework could be applied to identify the major drivers of differences in community response to deposited $\mathrm{N}$ in a range of habitat types. The trajectories of community change engendered by $\mathrm{N}$ deposition and other environmental stressors can be elucidated via a combination of approaches. Effective synthesis of globally distributed experiments, simulation modelling, and multi-region resurveys will help reveal the patterns, processes and functional consequences of context dependency in $\mathrm{N}$ deposition responses. Such a synthesis, a priority for future research including extension to under-investigated forested biomes and elsewhere, will allow refinement of conservation and restoration management guidelines and the effective determination of critical loads for plant communities.

\section{Declaration of interest}

None.

\section{Funding}

This work was primarily supported by the European Research Council, Consolidator Grant 614839. Data used for analysis derived from a number of funding sources as outlined in Acknowledgements. These funding sources had no involvement in the study design, collection, analysis, and interpretation of data, in writing the manuscript, and in the decision to submit the article for publication.

\section{Data statement}

Data supporting results are archived at a Ghent University institutional repository, and available through the forestREplot website. Original forest community resurvey data, also deposited at forestREplot, can be accessed by contacting the Management Committee (details on the website) who obtained individual permissions for data use from dataset contributors. Conflicting policies from funding sources at the time of the initial and more recent surveys prevent unsupervised public accessibility of raw vegetation resurvey data.

\section{Author contribution statement}

MPP performed the original literature search, which was then initially drafted into the review synthesis by DSC, FSG, JCJO and MBR (temperate forests), MD, AN and $\mathrm{P}-\mathrm{OH}$ (boreal forests), and FSG ((sub)tropical forests). MPP formulated the conceptual synthesis with input from MD and KV, while Daijiang Li drafted the final version of Fig. 1 after input from MPP, MD, HB and KV. HB drafted Fig. B1. MPP and GM performed the statistical analysis on the forestREplot data with KV and MD providing helpful suggestions. All authors from JB to KV, except both DL's, PM and DW, contributed data to these analyses (see also Acknowledgements). Thomas Dirnböck and SMS wrote the initial text on critical loads, and FM the initial text on restoration, conservation and management implications. MPP drafted the overall manuscript, which all authors commented on.

\section{Acknowledgements}

MPP and HB are, and Dries Landuyt was, supported by an European Research Council Consolidator Grant (614839: The PASTFORWARD project) awarded to KV. Dries Landuyt is currently supported by an FWO postdoctoral scholarship. Thomas Dirnböck was supported by the Wood-N-Climate project (ACRP7, KR14AC7K11858). The work by DSC and JCJO was supported by the LUBW Landesanstalt für Umwelt Baden-Württemberg, project StickstoffBW. MC and RH acknowledge the Grant Agency of the Czech Republic project No. 17-09283S for support leading to the presented research. Additional funding to MC and RH was provided by the long-term research development project RVO 67985939 of the Czech Academy of Sciences, a project also supporting MK and PP. PP further acknowledges support from the Centre of Excellence PLADIAS, no. 14-15414S (Czech Science Foundation). FM acknowledges support from VEGA 1/0639/17 and APVV-14-0086. We acknowledge contributors to forestREplot of data analysed herein including Keith Kirby, Lander Baeten, Guillaume Decocq, Thilo Heinken, Patrick Hommel, Bogdan Jaroszewicz, Fraser Mitchell, Tobias Naaf, Mitchell Newman, Hans Van Calster and Monika Wulf, and thank KK and TH for comments on an earlier draft. Jonathan 
Lenoir provided $\mathrm{R}$ code for figure presentation. We thank Roland Bobbink for discussions and literature suggestions at an early stage of this research, and two anonymous reviewers for constructive comments on an earlier draft.

\section{Appendix A. Supplementary data}

Supplementary data related to this article can be found at https://doi.org/10.1016/j.envpol.2018.07.089.

\section{References}

Akselsson, C., Belyazid, S., Hellsten, S., Klarqvist, M., Pihl-Karlsson, G., Karlsson, P.-E., et al., 2010. Assessing the risk of $\mathrm{N}$ leaching from forest soils across a steep N deposition gradient in Sweden. Environ. Pollut. 158, 3588-3595.

Averill, C., Waring, B., 2018. Nitrogen limitation of decomposition and decay: how can it occur? Global Change Biol. 24, 1417-1427.

Becker, T., Spanka, J., Schröder, L., Leuschner, C., 2017. Forty years of vegetation change in former coppice-with-standards woodlands as a result of management change and N deposition. Appl. Veg. Sci. 20, 304-313.

Bellard, C., Thuiller, W., Leroy, B., Genovesi, P., Bakkenes, M., Courchamp, F., 2013 Will climate change promote future invasions? Global Change Biol. 19, 3740-3748.

Bergkvist, B., Folkeson, L., 1995. The influence of tree species on acid deposition proton budgets and element fluxes in south Swedish forest ecosystems. Ecol. Bull. 44, 90-99.

Bernhardt-Römermann, M., Baeten, L., Craven, D., De Frenne, P., Hédl, R., Lenoir, J., et al., 2015. Drivers of temporal changes in temperate forest plant diversity vary across spatial scales. Global Change Biol. 21, 3726-3737.

Bernhardt-Römermann, M., Römermann, C., Pillar, V.D., Kudernatsch, T., Fischer, A 2010. High functional diversity is related to high nitrogen availability in a deciduous forest - evidence from a functional trait approach. Folia Geobot. 45, $111-124$.

Binkley, D., Högberg, P., 2016. Tamm Review: revisiting the influence of nitrogen deposition on Swedish forests. For. Ecol. Manag. 368, 222-239.

Bobbink, R., Hettelingh, J.P., 2011. Review and revision of empirical critical loads and dose-response relationships. In: Proceedings of an Expert Workshop, Noordwijkerhout 23-24 June 2010. RIVM Bilthoven, The Netherlands.

Bobbink, R., Hicks, K., Galloway, J., Spranger, T., Alkemade, R., Ashmore, M., et al. 2010. Global assessment of nitrogen deposition effects on terrestrial plant diversity: a synthesis. Ecol. Appl. 20, 30-59.

Bobbink, R., Hornung, M., Roelofs, J.G.M., 1998. The effects of air-borne nitrogen pollutants on species diversity in natural and semi-natural European vegetation. J. Ecol. 86, 717-738.

Borer, E.T., Harpole, W.S., Adler, P.B., Lind, E.M., Orrock, J.L., Seabloom, E.W., et al. 2014. Finding generality in ecology: a model for globally distributed experiments. Methods in Ecology and Evolution 5, 65-73.

Both, S., Fang, T., Baruffol, M., Schmid, B., Bruelheide, H., Erfmeier, A., 2012. Effects of tree sapling diversity and nutrient addition on herb-layer invasibility in communities of subtropical species. Open J. Ecol. 2, 1-11.

Box, E.O., 1996. Plant functional types and climate at the global scale. J. Veg. Sci. 7, $309-320$.

Boxman, A.W., Blanck, K., Brandrud, T.-E., Emmett, B.A., Gundersen, P., Hogervorst, R.F., et al., 1998. Vegetation and soil biota response to experimentally-changed nitrogen inputs in coniferous forest ecosystems of the NITREX project. For. Ecol. Manag. 101, 65-79.

Brunet, J., 1994. Interacting effects of $\mathrm{pH}$, aluminium and base cations on growth and mineral composition of the woodland grasses Bromus benekenii and Hor delymus europaeus. Plant Soil 161, 157-166.

Chudomelová, M., Hédl, R., Zouhar, V., Szabó, P., 2017. Open oakwoods facing modern threats: will they survive the next fifty years? Biol. Conserv. 210 $163-173$.

Corney, P.M., Kirby, K.J., Le Duc, M.G., Smart, S.M., McAllister, H.A., Marrs, R.H., 2008 Changes in the field-layer of Wytham Woods - assessment of the impacts of range of environmental factors controlling change. J. Veg. Sci. 19, 287-298.

De Frenne, P., Rodríguez-Sánchez, F., Coomes, D.A., Baeten, L., Verstraeten, G., Vellend, M., et al., 2013. Microclimate moderates plant responses to macroclimate warming. Proc. Natl. Acad. Sci. Unit. States Am. 110, 18561-18565.

De Frenne, P., Rodríguez-Sánchez, F., De Schrijver, A., Coomes, D.A., Hermy, M. Vangansbeke, P., et al., 2015. Light accelerates plant responses to warming. Nature Plants 1,15110.

De Vries, W., Dobbertin, M.H., Solberg, S., van Dobben, H.F., Schaub, M., 2014. Impacts of acid deposition, ozone exposure and weather conditions on forest ecosystems in Europe: an overview. Plant Soil 380, 1-45.

De Vries, W., Hettelingh, J.P., Posch, M., 2015. Critical Loads and Dynamic Risk Assessments - Nitrogen, Acidity and Metals in Terrestrial and Aquatic Ecosystems. Springer, Dordrecht.

De Vries, W., Wamelink, G.W.W., van Dobben, H., Kros, J., Reinds, G.J., MolDijkstra, J.P., et al., 2010. Use of dynamic soil-vegetation models to assess impacts of nitrogen deposition on plant species composition: an overview. Ecol Appl. 20, 60-79.
Decocq, G., Aubert, M., Dupont, F., Alard, D., Saguez, R., Wattez-Franger, A., et al., 2004. Plant diversity in a managed temperate deciduous forest: understorey response to two silvicultural systems. J. Appl. Ecol. 41, 1065-1079.

Diekmann, M., 2003. Species indicator values as an important tool in applied plant ecology - a review. Basic Appl. Ecol. 4, 493-506.

Diekmann, M., Dupré, C., 1997. Acidification and eutrophication of deciduous forests in northwestern Germany demonstrated by indicator species analysis. J. Veg. Sci. 8, 855-864.

Diekmann, M., Falkengren-Grerup, U., 1998. A new species index for forest vascular plants: development of functional indices based on mineralization rates of various forms of soil nitrogen. J. Ecol. 86, 269-283.

Douda, J., Boublík, K., Doudová, J., Kyncl, M., 2017. Traditional forest management practices stop forest succession and bring back rare plant species. J. Appl. Ecol. $54,761-771$.

Duprè, C., Stevens, C.J., Ranke, T., Bleeker, A., Peppler-Lisbach, C., Gowing, D.J.G., et al., 2010. Changes in species richness and composition in European acidic grasslands over the past 70 years: the contribution of cumulative atmospheric nitrogen deposition. Global Change Biol. 16, 344-357.

Dzwonko, Z., 2001. Assessment of light and soil conditions in ancient and recent woodlands by Ellenberg indicator values. J. Appl. Ecol. 38, 942-951.

Falkengren-Grerup, U., 1990. Distribution of field layer species in Swedish deciduous forests in 1929-54 and 1979-88 as related to soil pH. Veg. Acta Geobot. 86, $143-150$.

Falkengren-Grerup, U., 1995. Interspecies differences in the preference of ammonium and nitrate in vascular plants. Oecologia 102, 305-311.

Falkengren-Grerup, U., Månsson, K.F., Olsson, M.O., 2000. Uptake capacity of amino acids by ten grasses and forbs in relation to soil acidity and nitrogen availability. Environ. Exp. Bot. 44, 207-219.

Fraser, L.H., Henry, H.A., Carlyle, C.N., White, S.R., Beierkuhnlein, C., Cahill, J.F., et al., 2013. Coordinated distributed experiments: an emerging tool for testing global hypotheses in ecology and environmental science. Front. Ecol. Environ. 11, $147-155$.

George, L.O., Bazzaz, F.A., 2014. The herbaceous layer as a filter determining spatial pattern in forest tree regeneration. In: Gilliam, F.S. (Ed.), The Herbaceous Layer in Forests of Eastern North America. Oxford University Press New York.

Gillespie, M.A.K., Baude, M., Biesmeijer, J., Boatman, N., Budge, G.E., Crowe, A., et al., 2017. A method for the objective selection of landscape-scale study regions and sites at the national level. Methods in Ecology and Evolution 8, 1468-1476.

Gilliam, F.S., 2006. Response of the herbaceous layer of forest ecosystems to excess nitrogen deposition. J. Ecol. 94, 1176-1191.

Gilliam, F.S., 2007. The ecological significance of the herbaceous layer in temperate forest ecosystems. Bioscience 57, 845-858.

Gilliam, F.S., Welch, N.T., Phillips, A.H., Billmyer, J.H., Peterjohn, W.T., Fowler, Z.K., et al., 2016. Twenty-five year response of the herbaceous layer of a temperate hardwood forest to elevated nitrogen deposition. Ecosphere 7, e01250.

Göransson, P., Olsson, P.A., Postma, J., Falkengren-Grerup, U., 2008. Colonisation by arbuscular mycorrhizal and fine endophytic fungi in four woodland grasses variation in relation to $\mathrm{pH}$ and aluminium. Soil Biol. Biochem. 40, 2260-2265.

Grainger, T.N., Turkington, R., 2013. Mechanisms for success after long-term nutrient enrichment in a boreal forest understory. PLoS One 8, e61229.

Hättenschwiler, S., Körner, C., 1997. Biomass allocation and canopy development in spruce model ecosystems under elevated $\mathrm{CO}_{2}$ and increased $\mathrm{N}$ deposition. Oecologia 113, 104-114.

Hedwall, P.-O., Bergh, J., Brunet, J., 2017a. Phosphorus and nitrogen co-limitation of forest ground vegetation under elevated anthropogenic nitrogen deposition. Oecologia 185, 317-326.

Hedwall, P.-O., Brunet, J., 2016. Trait variations of ground flora species disentangle the effects of global change and altered land-use in Swedish forests during 20 years. Global Change Biol. 22, 4038-4047.

Hedwall, P.-O., Brunet, J., Rydin, H., 2017b. Peatland plant communities under global change: negative feedback loops counteract shifts in species composition. Ecology 98, 150-161.

Hedwall, P.-O., Churski, M., Jędrzejewska, B., Miścicki, S., Kuijper, D.P.J., 2018. Functional composition of temperate forest trees under chronic ungulate herbivory. J. Veg. Sci. 29, 179-188.

Heinrichs, S., Schmidt, W., 2017. Biotic homogenization of herb layer composition between two contrasting beech forest communities on limestone over 50 years. Appl. Veg. Sci. 20, 271-281.

Henrys, P.A., Stevens, C.J. Smart, S.M., Maskell, L.C., Walker, K.J., Preston, C.D. et al., 2011. Impacts of nitrogen deposition on vascular plants in Britain: an analysis of two national observation networks. Biogeosciences 8, 3501-3518.

Hettelingh, J.-P., Posch, M., Slootweg, J., 2017. European critical loads: database, biodiversity and ecosystems at risk, CCE Final Report 2017. In: Coordination Centre for Effects, RIVM Report 2017-0155. RIVM Bilthoven, Netherlands.

Hofmeister, J., Mihaljevič, M., Hošek, J., Sádlo, J., 2002. Eutrophication of deciduous forests in the Bohemian Karst (Czech Republic): the role of nitrogen and phosphorus. For. Ecol. Manag. 169, 213-230.

Houlton, B.Z., Morford, S.L., Dahlgren, R.A., 2018. Convergent evidence for widespread rock nitrogen sources in Earth's surface environment. Science 360, 58-62.

Jantsch, M.C., Fischer, A., Fischer, H.S., Winter, S., 2013. Shift in plant species composition reveals environmental changes during the last decades: a longterm study in beech (Fagus sylvatica) forests in Bavaria, Germany. Folia Geobot. $48,467-491$.

Keith, S.A., Newton, A.C., Morecroft, M.D., Bealey, C.E., Bullock, J.M., 2009. 
Taxonomic homogenization of woodland plant communities over 70 years. Proc. R. Soc. Lond. B Biol. Sci. 276, 3539-3544.

Lameire, S., Hermy, M., Honnay, O., 2000. Two decades of change in the ground vegetation of a mixed deciduous forest in an agricultural landscape. J. Veg. Sci. 11, 695-704.

Landuyt, D., Perring, M.P., Seidl, R., Taubert, F., Verbeeck, H., Verheyen, K., 2018. Modelling understorey dynamics in temperate forests under global change-Challenges and perspectives. Perspect. Plant Ecol. Evol. Systemat. 31, 44-54.

Lee, J.A., 1998. The calcicole-calcifuge problem revisited. In: Callow, J.A. (Ed.), Advances in Botanical Research. Academic Press, pp. 1-30.

Leuschner, C., Ellenberg, H., 2017. Ecology of Central European Forests. Vegetation Ecology of Central Europe, Volume I. Revised and Extended Version of the 6th German Edition. Translated by Laura Sutcliffe. Springer, Switzerland.

Lovett, G.M., Weathers, K.C., Arthur, M.A., Schultz, J.C., 2004. Nitrogen cycling in a northern hardwood forest: do species matter? Biogeochemistry 67, 289-308.

Lu, X., Mao, Q., Gilliam, F., Luo, Y., Mo, J., 2014. Nitrogen deposition contributes to soil acidification in tropical ecosystems. Global Change Biol. 20, 3790-3801.

Lu, X., Mo, J., Gilliam, F.S., Yu, G., Zhang, W., Fang, Y., et al., 2011. Effects of experimental nitrogen additions on plant diversity in tropical forests of contrasting disturbance regimes in southern China. Environ. Pollut. 159, 2228-2235.

Lu, X., Mo, J., Gilliam, F.S., Zhou, G., Fang, Y., 2010. Effects of experimental nitrogen additions on plant diversity in an old-growth tropical forest. Global Change Biol. 16, 2688-2700.

Matthews, J.D., 1989. Silvicultural Systems. Oxford University Press, Oxford.

McDonnell, T.C., Belyazid, S., Sullivan, T.J., Sverdrup, H., Bowman, W.D., Porter, E.M., 2014. Modeled subalpine plant community response to climate change and atmospheric nitrogen deposition in Rocky Mountain National Park, USA. Environ. Pollut. 187, 55-64.

McGrath, M.J., Luyssaert, S., Meyfroidt, P., Kaplan, J.O., Bürgi, M., Chen, Y., et al., 2015. Reconstructing European forest management from 1600 to 2010. Biogeosciences 12, 4291-4316.

Müllerová, J., Hédl, R., Szabó, P., 2015. Coppice abandonment and its implications for species diversity in forest vegetation. For. Ecol. Manag. 343, 88-100.

Naaf, T., Kolk, J., 2016. Initial site conditions and interactions between multiple drivers determine herb-layer changes over five decades in temperate forests. For. Ecol. Manag. 366, 153-165.

Nakagawa, S., Schielzeth, H., 2013. A general and simple method for obtaining $\mathrm{R}^{2}$ from generalized linear mixed-effects models. Methods in Ecology and Evolution 4, 133-142.

Näsholm, T., Ekblad, A., Nordin, A., Giesler, R., Högberg, M., Högberg, P., 1998. Boreal forest plants take up organic nitrogen. Nature 392, 914-916.

Nilsson, J., Grennfelt, P., 1988. Critical Loads for Sulphur and Nitrogen. Nordic Council of Ministers Copenhagen.

Nilsson, L.O., Bååth, E., Falkengren-Grerup, U., Wallander, H., 2007. Growth of ectomycorrhizal mycelia and composition of soil microbial communities in oak forest soils along a nitrogen deposition gradient. Oecologia 153, 375-384.

Nilsson, M.-C., Wardle, D.A., 2005. Understory vegetation as a forest ecosystem driver: evidence from the northern Swedish boreal forest. Front. Ecol. Environ. 3, 421-428.

Nordén, U., 1991. Acid deposition and throughfall fluxes of elements as related to tree species in deciduous forests of South Sweden. Water Air Soil Pollut. 60, 209-230.

Nordin, A., Strengbom, J., Forsum, Å., Ericson, L., 2009. Complex biotic interactions drive long-term vegetation change in a nitrogen enriched boreal forest. Ecosystems 12, 1204-1211.

Nordin, A., Strengbom, J., Witzell, J., Näsholm, T., Ericson, L., 2005. Nitrogen deposition and the biodiversity of boreal forests: implications for the nitrogen critical load. Ambio 34, 20-24.

Norland, E.R., Hix, D.M., 1996. Composition and structure of a chronosequence of young, mixed-species forests in southeastern Ohio, USA. Veg. Acta Geobot. 125, $11-30$.

Ochoa-Hueso, R., Munzi, S., Alonso, R., Arróniz-Crespo, M., Avila, A., Bermejo, V., et al., 2017. Ecological impacts of atmospheric pollution and interactions with climate change in terrestrial ecosystems of the Mediterranean Basin: current research and future directions. Environ. Pollut. 227, 194-206.

Pardo, L.H., Fenn, M.E., Goodale, C.L., Geiser, L.H., Driscoll, C.T., Allen, E.B., et al., 2011. Effects of nitrogen deposition and empirical nitrogen critical loads for ecoregions of the United States. Ecol. Appl. 21, 3049-3082.

Payne, R.J., Dise, N.B., Field, C.D., Dore, A.J., Caporn, S.J., Stevens, C.J., 2017. Nitrogen deposition and plant biodiversity: past, present, and future. Front. Ecol. Environ. $15,431-436$.

Payne, R.J., Dise, N.B., Stevens, C.J., Gowing, D.J., BEGIN Partners, 2013. Impact of nitrogen deposition at the species level. Proc. Natl. Acad. Sci. Unit. States Am. 110, 984-987.

Perring, M.P., Bernhardt-Römermann, M., Baeten, L., Midolo, G., Blondeel, H., Depauw, L., et al., 2018. Global environmental change effects on plant community composition trajectories depend upon management legacies. Global Change Biol. 24, 1722-1740.

Perring, M.P., De Frenne, P., Baeten, L., Maes, S.L., Depauw, L., Blondeel, H., et al., 2016. Global environmental change effects on ecosystems: the importance of land-use legacies. Global Change Biol. 22, 1361-1371.

Perring, M.P., Hedin, L.O., Levin, S.A., McGroddy, M., de Mazancourt, C., 2008. Increased plant growth from nitrogen addition should conserve phosphorus in terrestrial ecosystems. Proc. Natl. Acad. Sci. Unit. States Am. 105, 1971-1976.

Phoenix, G.K., Hicks, W.K., Cinderby, S., Kuylenstierna, J.C.I., Stock, W.D.,
Dentener, F.J., et al., 2006. Atmospheric nitrogen deposition in world biodiversity hotspots: the need for a greater global perspective in assessing $\mathrm{N}$ deposition impacts. Global Change Biol. 12, 470-476.

Pinheiro, J., Bates, D., DebRoy, S., Sarkar, D., R Core Team, 2016. Linear and Nonlinear Mixed Effects Models. R Package Version 3.1-128._nlme.

Rackham, O., 2003. Ancient Woodland: its History, Vegetation and Uses in England. Castlepoint Press, Dalbeattie.

Ramalho, C.E., Hobbs, R.J., 2012. Time for a change: dynamic urban ecology. Trends Ecol. Evol. 27, 179-188.

R Core Team, 2017. R: a Language and Environment for Statistical Computing. R Foundation for Statistical Computing, Vienna, Austria. Retrieved from http:// www.R-project.org/.

Reczyńska, K., Świerkosz, K., 2017. Compositional changes in thermophilous oak forests in Poland over time: do they correspond to European trends? Appl. Veg. Sci. 20, 293-303.

Rizzetto, S., Belyazid, S., Gégout, J.-C., Nicolas, M., Alard, D., Corcket, E., et al., 2016 Modelling the impact of climate change and atmospheric $\mathrm{N}$ deposition on French forests biodiversity. Environ. Pollut. 213, 1016-1027.

Rodenkirchen, H., 1992. Effects of acidic precipitation, fertilization and liming on the ground vegetation in coniferous forests of southern Germany. Water Air Soil Pollut. 61, 279-294.

Savage, J., Vellend, M., 2015. Elevational shifts, biotic homogenization and time lags in vegetation change during 40 years of climate warming. Ecography 38 , 546-555.

Schaffers, A.P., Sýkora, K.V., 2000. Reliability of Ellenberg indicator values for moisture, nitrogen and soil reaction: a comparison with field measurements. J. Veg. Sci. 11, 225-244.

Senior, R.A., Hill, J.K., Benedick, S., Edwards, D.P., 2018. Tropical forests are thermally buffered despite intensive selective logging. Global Change Biol. 24, 1267-1278.

Simkin, S.M., Allen, E.B., Bowman, W.D., Clark, C.M., Belnap, J., Brooks, M.L., et al., 2016. Conditional vulnerability of plant diversity to atmospheric nitrogen deposition across the United States. Proc. Natl. Acad. Sci. Unit. States Am. 113, 4086-4091.

Smart, S.M., Ellison, A.M., Bunce, R.G.H., Marrs, R.H., Kirby, K.J., Kimberley, A., et al., 2014. Quantifying the impact of an extreme climate event on species diversity in fragmented temperate forests: the effect of the October 1987 storm on British broadleaved woodlands. J. Ecol. 102, 1273-1287.

Smart, S.M., Henrys, P.A., Purse, B.V., Murphy, J.M., Bailey, M.J., Marrs, R.H., 2012 Clarity or confusion? - Problems in attributing large-scale ecological changes to anthropogenic drivers. Ecol. Indicat. 20, 51-56.

Stevens, C.J., 2016. How long do ecosystems take to recover from atmospheric nitrogen deposition? Biol. Conserv. 200, 160-167.

Stevens, C.J., Manning, P., van den Berg, L.J.L., de Graaf, M.C.C., Wamelink, G.W.W. Boxman, A.W., et al., 2011. Ecosystem responses to reduced and oxidised nitrogen inputs in European terrestrial habitats. Environ. Pollut. 159, 665-676.

Strengbom, J., Axelsson, E.P., Lundmark, T., Nordin, A., Villard, M.A., 2018. Trade-offs in the multi-use potential of managed boreal forests. J. Appl. Ecol. 55, 958-966.

Strengbom, J., Näsholm, T., Ericson, L., 2004. Light, not nitrogen, limits growth of the grass Deschampsia flexuosa in boreal forests. Can. J. Bot. 82, 430-435.

Strengbom, J., Nordin, A., 2012. Physical disturbance determines effects from nitrogen addition on ground vegetation in boreal coniferous forests. J. Veg. Sci. 23, $361-371$.

Strengbom, J., Nordin, A., Näsholm, T., Ericson, L., 2001. Slow recovery of boreal forest ecosystem following decreased nitrogen input. Funct. Ecol. 15, 451-457.

Strengbom, J., Nordin, A., Näsholm, T., Ericson, L., 2002. Parasitic fungus mediates change in nitrogen-exposed boreal forest vegetation. J. Ecol. 90, 61-67.

Suding, K.N., Collins, S.L., Gough, L., Clark, C., Cleland, E.E., Gross, K.L., et al., 2005 Functional- and abundance-based mechanisms explain diversity loss due to $\mathrm{N}$ fertilisation. Proc. Natl. Acad. Sci. Unit. States Am. 102, 4387-4392.

Suding, K.N., Lavorel, S., Chapin III, F.S., Cornelissen, J.H.C., Diaz, S., Garnier, E., et al., 2008. Scaling environmental change through the community-level: a traitbased response-and-effect framework for plants. Global Change Biol. 14, 1125-1140

Tessier, J.T., Raynal, D.J., 2003. Use of nitrogen to phosphorus ratios in plant tissue as an indicator of nutrient limitation and nitrogen saturation. J. Appl. Ecol. 40, 523-534.

Thimonier, A., Dupouey, J.L., Timbal, J., 1992. Floristic changes in the herb-layer vegetation of a deciduous forest in the Lorraine Plain under the influence of atmospheric deposition. For. Ecol. Manag. 55, 149-167.

Thom, D., Seidl, R., 2016. Natural disturbance impacts on ecosystem services and biodiversity in temperate and boreal forests. Biol. Rev. 91, 760-781.

Thrippleton, T., Bugmann, H., Kramer-Priewasser, K., Snell, R.S., 2016. Herbaceous understorey: an overlooked player in forest landscape dynamics? Ecosystems 19, 1240-1254.

Treseder, K.K., Vitousek, P.M., 2001. Effects of soil nutrient availability on investment in acquisition of $\mathrm{N}$ and $\mathrm{P}$ in Hawaiian rain forests. Ecology 82, 946-954.

Vellend, M., 2010. Conceptual synthesis in community ecology. Q. Rev. Biol. 85, 183-206.

Verheyen, K., Baeten, L., De Frenne, P., Bernhardt-Römermann, M., Brunet, J., Cornelis, J., et al., 2012. Driving factors behind the eutrophication signal in understorey plant communities of deciduous temperate forests. J. Ecol. 100, 352-365.

Verheyen, K., De Frenne, P., Baeten, L., Waller, D.M., Hédl, R., Perring, M.P., et al., 2017. Combining biodiversity resurveys across regions to advance global change research. Bioscience 67, 73-83. 
Verstraeten, A., Neirynck, J., Genouw, G., Cools, N., Roskams, P., Hens, M., 2012. Impact of declining atmospheric deposition on forest soil solution chemistry in Flanders, Belgium. Atmos. Environ. 62, 50-63.

Vild, O., Roleček, J., Hédl, R., Kopecký, M., Utinek, D., 2013. Experimental restoration of coppice-with-standards: response of understorey vegetation from the conservation perspective. For. Ecol. Manag. 310, 234-241.
Wamelink, G.W.W., Joosten, V., van Dobben, H.F., Berendse, F., 2002. Validity of Ellenberg indicator values judged from physico-chemical field measurements. J. Veg. Sci. 13, 269-278.

Zuur, A.F., Ieno, E.N., Walker, N.J., Saveliev, A.A., Smith, G.M., 2009. Mixed Effects Models and Extensions in Ecology with R. Springer, New York. 